\title{
Reference Desk Service: Success or Failure?
}

\author{
Norazlin H. ${ }^{1}$, Che Rusuli M. S. ${ }^{2}$, Tasmin R. ${ }^{2}$, Norliya Ahmad Kassim ${ }^{3}$ \& Alhaji Abubakar Aliyu ${ }^{2}$ \\ ${ }^{1}$ Department of Information Technology, Center for Diploma Studies, Universiti Tun Hussein Onn Malaysia, \\ Batu Pahat, Malaysia \\ ${ }^{2}$ Department of Production and Operation Management, Faculty of Technology Management and Business, \\ Universiti Tun Hussein Onn Malaysia, Batu Pahat, Malaysia \\ ${ }^{3}$ Faculty of Information Management, Universiti Teknologi MARA Puncak Perdana Campus, No.1, Jalan Pulau \\ Angsa AU10/A, Section U10Shah Alam, Selangor, Malaysia \\ Correspondence: Norazlin H., Department of Information Technology, Center for Diploma Studies, Universiti \\ Tun Hussein Onn Malaysia, 86400 Batu Pahat, Malaysia. E-mail: norazlin@uthm.edu.my
}

Received: October 6, 2014 Accepted: January 26, 2015 Online Published: April 20, 2015

doi:10.5539/ass.v11n10p168

URL: http://dx.doi.org/10.5539/ass.v11n10p168

\begin{abstract}
At present, research related to library user satisfaction is a never ending journey. With this regard, this study seeks to assess the reference desk services and the users' satisfaction level at Malaysian academic libraries. Twenty respondents from Perpustakaan Tun Abdul Razak Library (PTAR), Universiti Teknologi Mara (UiTM) Shah Alam and Perpustakaan Tunku Tun Aminah Library (PTTA), Universiti Tun Hussein Onn Malaysia Johor was involved in this study. The result revealed that students of both libraries expressed the needs of services rendered by the reference desk, in terms of the usage and importance of the reference desk. Specifically, UTHM students preferred and online information searching compared to UiTM students. This means that, libraries can provide specific services to students who underutilized the reference desk. Hence, this study is used to seek whether reference desk services are still relevant (success) or not (failure) when experiencing declining reference desk services from the students' perspective. It is hoped that the findings of this study will be beneficial for increasing level of user satisfaction in order to retain reference desk services in the library.
\end{abstract}

Keywords: academic libraries, reference desk, desk service, Malaysia

\section{Introduction}

At present, the advents of information and communication technology (ICT) has given impact to academic libraries that passionately looked for ways to effectively render their services to their users in a more user friendly platform. This means that reference librarians have to comprehend and embrace the recent emerging technology, so as to improve the services of the reference desk. Moreover, this is as a result of perpetual changes that revolved around libraries as a result of socioeconomic changes. Today, reference desk services are considered to be the heart of libraries in all sectors, whether academic, public or special libraries. In essence, it was the responsibility of librarians to provide information directly to the library user. Though, rising of information and communication technology offered difficulties to the librarians on the obligation of rendering reference desk services, not much research has been conducted to evaluate the impact of these services (Nordin, Kassim, \& Baharuddin, 2012). Collins (2005) conducted a study on the students of College Dublin, in which he reported that $56 \%$ of the students asked their colleagues related questions on library, rather than the librarians. This means that, librarians have the tendency to visualize their users as a long term user, or else the users will find the use of their services irrelevant or not necessary. A study conducted by Vondracek (2007) reported that majority of library users are unaware of librarians' capability in rendering services or have specialties on the subject matter. Iberahim and Nadzar (2011) reported that $18 \%$ of library users rarely use reference desk (at least monthly), while user inquiries increased by $40 \%$. This means that, in the long run this issue could have a significant effect on the services rendered by the reference desk and by extension this could affect the future planning of library services (Sobel, 2009). Consequently, the growth of the digital reference desk as a result of information and communication technology is the latest trend in the digital era in providing reference desk services. The reference desk has made users to have easy access to digital information at the fingertips. The purpose of this study was to assess and improve the effectiveness of reference desk services in meeting users' 
needs and demand. Hence, two objectives were postulated, which are (1) to identify library services that were often used by library users and (2) to assess the 'level of satisfaction' of reference desk services. In this regard, the evaluations about the relevancy of reference desk services at Malaysian academic libraries need to be taken into consideration with the fact that library users like to use information technologies.

\section{Method}

This study comprised of ten (10) respondents from Tun Abdul Razak Library (PTAR), Universiti Teknologi Mara (UiTM) Shah Alam and ten (10) respondents from Tunku Tun Aminah Library (PTTA), Universiti Tun Hussein Onn Malaysia Johor. The respondents were selected based on convenient sampling. The first reason why the researchers adopted convenience sampling is because convenience sampling is faster unlike other sampling techniques that may require a researcher to involve some technicalities. Secondly, convenience sampling is inexpensive, easy and more often the respondents are readily available. Hence, twenty (20) questionnaires were distributed at PTAR and PTTA users, whereby the total $100 \%$ response rate was returned. The close and open ended questionnaires applied in this study consisted of 3 parts with 18 questions. Part "A" dealt with the demographics and Part "B" listed questions that were meant to collect data for the reference desk services, i.e. use of the reference desk, where to go for help, reason for never visiting the reference desk, while Part "C" collected data on the comment and suggestion. In all, data collected were analyzed by using frequencies and percentages.

\section{Findings}

The total respondents $(100 \%)$ are from two university libraries, which are ten respondents from Universiti Tun Hussein Onn Malaysia (UTHM) and 10 respondents from Universiti Teknologi Mara (UiTM). Figure 1 shows that the majority (60\%) of the respondent belongs to the age group of $25-27$ years old followed by those (25\%) in the age group of $28-30$ years old. The other $10 \%$ are within $19-21$ years old. Only $5 \%$ are in the age group of 22-24 years old.

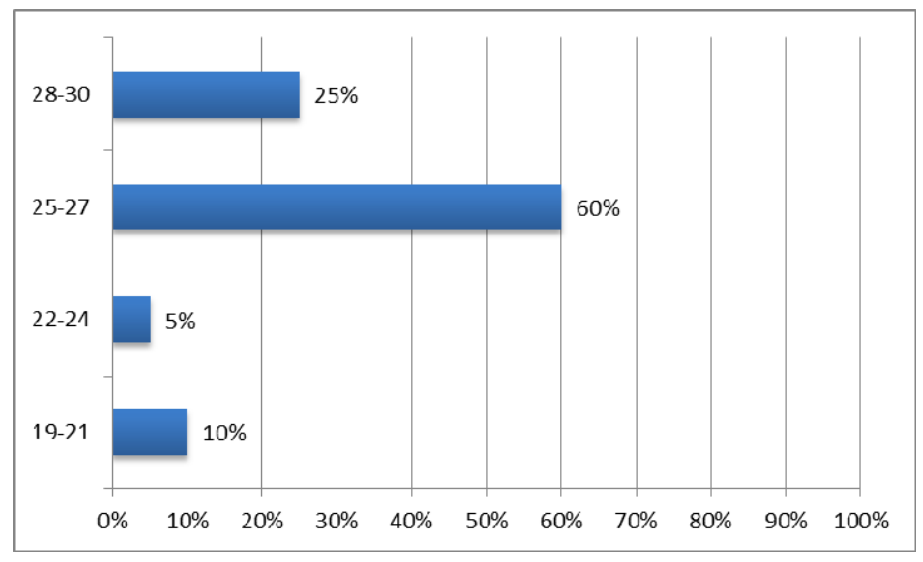

Figure 1. Age of respondents

Figure 2 presents the result of responses acquired from each university on where there go for help when they have a question about finding information. The majority (70\%) of the respondents in UTHM like to use the welcome desk compared to UiTM (10\%). However, $40 \%$ of the respondents at UiTM like to use the circulation desk but none $(0 \%)$ at UTHM. Besides, $50 \%$ of respondents from UiTM like to use advisory reference desk compared to $30 \%$ at UTHM. Surprisingly, none $(0 \%)$ of the respondents from UiTM and UTHM libraries use the other services (i.e. E-mail, Ask a librarian, Chat, FAQ, User Feedback form service and Collaborative Reference Service). 


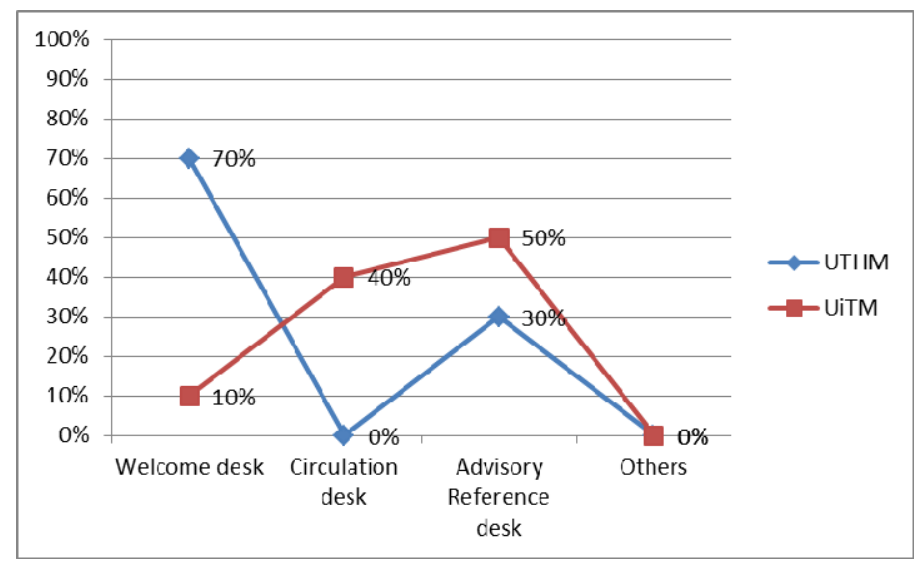

Figure 2. Where to go for help

Figure 3 indicates the result of respondents in using the Reference Desk. The results show that $80 \%$ of UiTM respondents use the Reference Desk compared to $40 \%$ of UTHM respondents. However, $60 \%$ of UTHM respondents did not use the Reference desk compared to $20 \%$ of UiTM respondents. This is possible because of the information technology (IT) took place in searching information around the globe.



Figure 3. Use of reference desk

Figure 4 presents the result of respondents' frequency of using the Reference desk. The results show that both UTHM and UiTM respondents ( $10 \%$ respectively) used the Reference desk once a week. On the other hand, the majority $(80 \%)$ of UTHM respondents used the Reference desk twice a week compared to UiTM respondents $(30 \%)$. Half $(50 \%)$ of UiTM respondents used the reference desk services three times a week. However, both UiTM and UTHM respondents ( $10 \%$ respectively) rated "Others" in using the reference desk service.

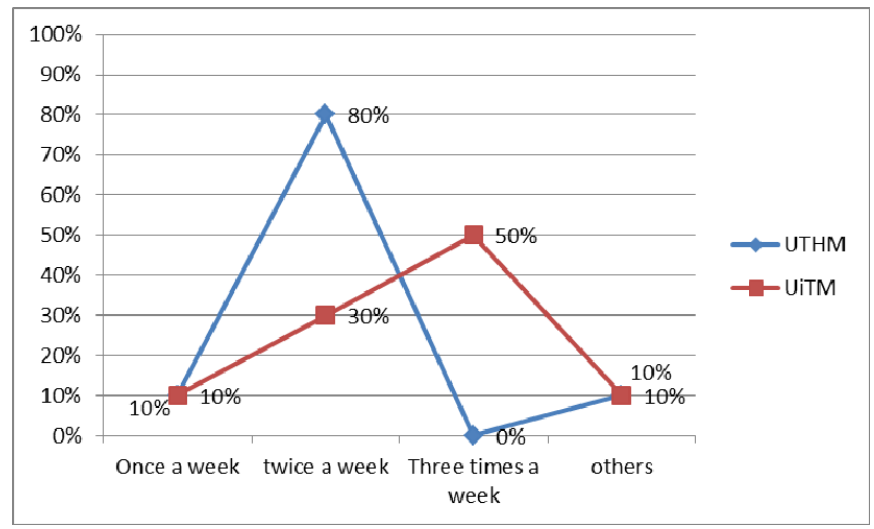

Figure 4. Reference desk's frequency of usage 
Figure 5 indicates the result of the reason why the students have never visited the reference desk. About $10 \%$ of UiTM respondents did not know where the reference desk is located while UTHM respondent did not rate any. Besides, $10 \%$ of UiTM respondents already know about the information. The majority (80\%) of UiTM respondents claimed that they don't have a time to use reference desk. All (100\%) of UTHM respondents prefer online searching rather than visiting the desk service. Therefore, Figure 5 indicates an interesting significant gap between respondents in PTTA UTHM and PTAR UiTM. In this regard, users at PTAR UiTM did not depend so much on online searching because they learned and understand that information could be retrieved in any format (e.g. Almanac, Cassette, Video Tapes, Newspaper Cutting, etc.) everywhere at any time. These results are the outcomes from the collection, interpretation, analysis and evaluation of data. In fact, the value of this study (e.g. Figure 5) will become a contribution to the body of knowledge, so that, they could further study to perceive why users recently become so excited and dependent in using online searching.

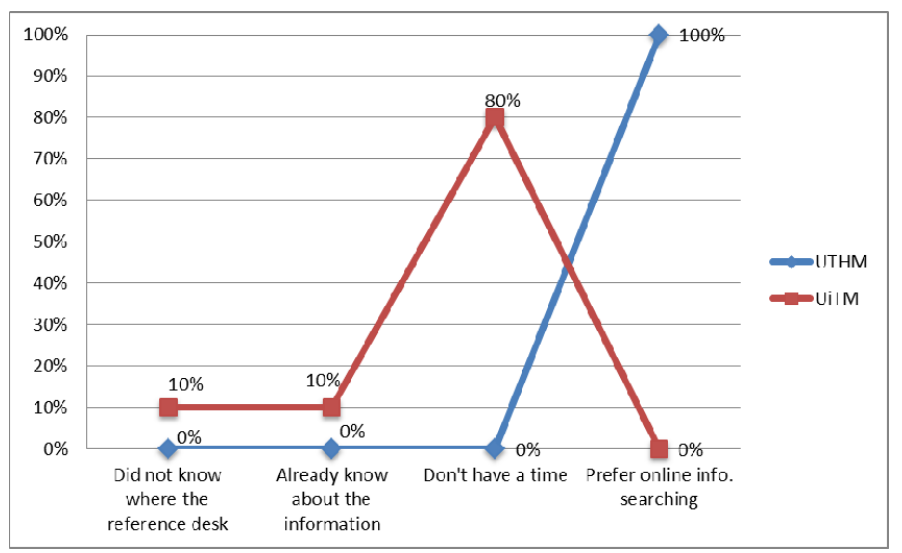

Figure 5. Reason for never visiting the reference desk

Figure 6 indicates the results of the satisfaction level of library reference desk service. Ten percent of UiTM respondents are not satisfied with the library reference desk service compared to $20 \%$ of UTHM. However, the majority ( $80 \%$ respectively) of respondents of UiTM and UTHM are satisfied with the reference desk service. Another $10 \%$ of UiTM respondents are very satisfied, however, none of the UTHM respondents are very satisfied with the reference desk service.

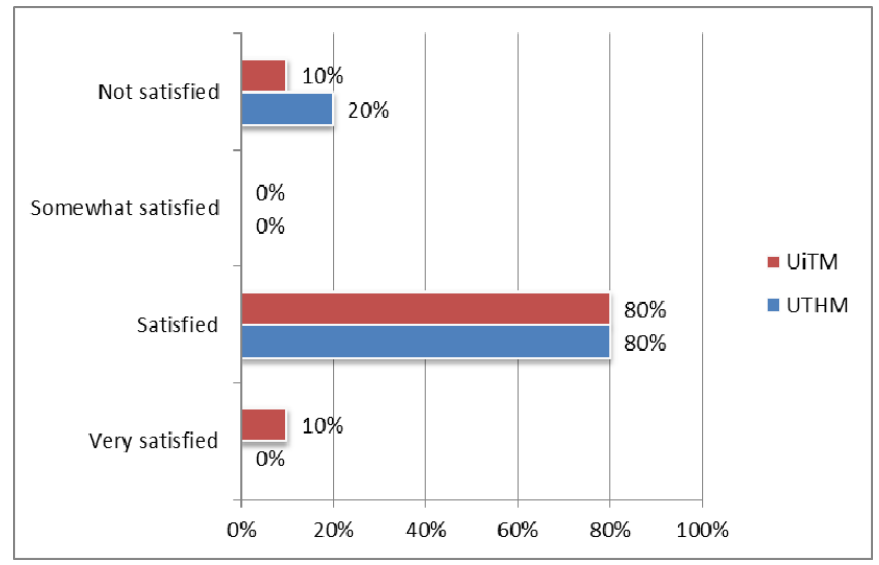

Figure 6. Level of satisfaction

\section{Discussion}

The relevancy of reference desk service in the university libraries depends on the customers demand. After presenting the findings, the objectives of the study were achieved. Firstly, respondents from both universities agreed that they do practice using welcome desk, circulation desk and reference desk in finding information. These findings lead to some understanding of the working conditions of para-professionals at information and reference desks (Rieh, 1999). Librarians and desk staff currently need to explore the possibility of desk staff 
assisting liaisons with creating online subject guides and engaging, in other activities, to give the staff important experience and to assist liaisons with substantial non-liaison duties (Schulte, 2011). Furthermore, customers needing in-depth consultations with a reference librarian, which they want to asked everything when they need help during reference desk hours.

Secondly, the level of user satisfaction presents almost $80 \%$ of the respondents of both universities who are satisfied with reference desk service. A study done by Garrison revealed that $80 \%$ of reference desk statistics and questions kept through Library Statistics (LibStats) had already informed what other academic libraries were already reporting. The majority of transactions could be answered by well trained staff and student assistants and the library had already shifted to staffing the majority of desk hours with student staff (Garrison, 2011). At this point, policy maker's (e.g. Chief Librarian) decision should be made to change the functions and capabilities of reference desk service in the digital age. For instance, the changing function and capabilities of reference desk service from physical into Online/Virtual environment in the technological era to encounter customers demand-sentence incomplete. It is important to continuously thrive for deriving tools and techniques where the individual user gets the feel of connectivity with their information providers.

In this transition, Garrison (2011) noted that university libraries have identified several weaknesses with current practices and they are working toward making adjustments to improve the service. These include increased training and cross-departmental communication. The new library in the digital environment will also provide users with a different desk model (Garrison, 2011, Polger \& Okamoto, 2010), consisting of several smaller pods that will allow working collaboratively with students. In this regard, Nolen (2010) recommended all questions that were asked by library users can become easier to apply in the context of chat or email reference. Therefore, these services allow librarians to enter an extended reference encounter with a patron/user. For example, Chat programs that librarians can walk a user through a complex search, with the user having the opportunity to perform the search on their own, but with the librarian "virtually" nearby in the event that he or she runs into difficulty. As to collaborative live virtual reference, Malik and Mahmood (2014) and Light et al. (2014) stated most librarians were aware that in America it became a trend to provide reference service through instant message as depicted in Figure 7. In fact, many libraries are offering or advancing towards digital reference service (DRS) with the intention to meet users' needs anytime, anywhere (Malik \& Mahmood, 2014). However, most respondents thought that face-to-face service was still not replaceable. This study suggests that Malaysian academic libraries should execute this system to be more interactive and always keep in touch with their users when needed.

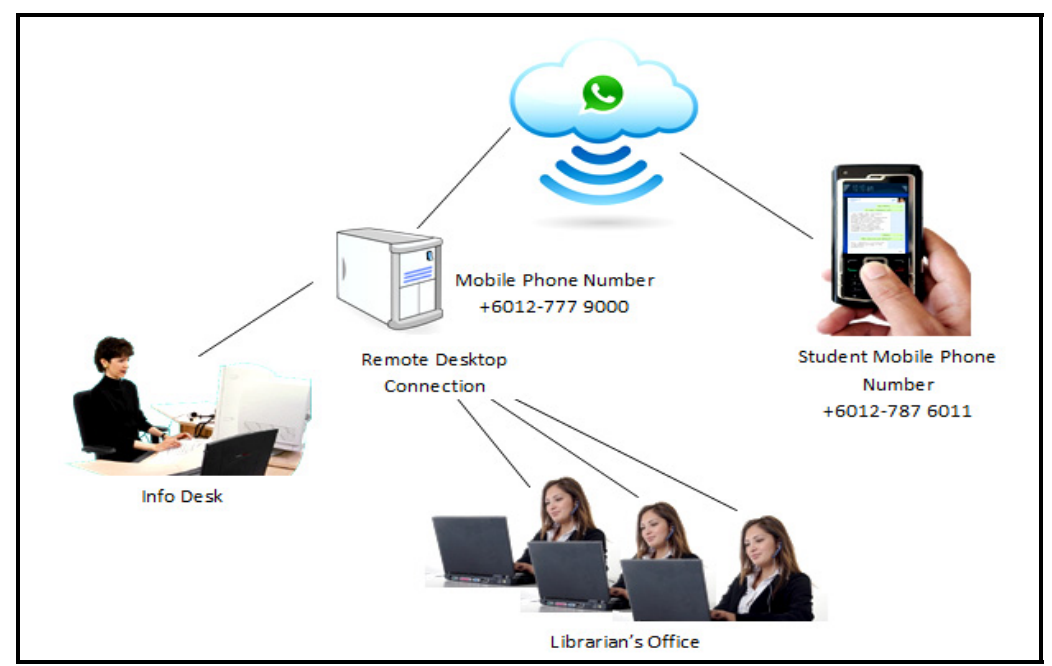

Figure 7. Reference service through instant messaging

Source: Hong Kong University Science and Technology (HKUST) reference service

This study investigated the overall user's perception and satisfaction with reference services in university libraries between UTHM library and UiTM library. This study urges to assess user 'level of satisfaction' of reference desk service in Malaysia. The researchers hope that this study will further motivate the future research. The study's results suggested that user needs and demands should pay attention for the improvement of the 
present level of user satisfaction.

Keeping this reality into view, the survey was an initial step for finding the status of such activities in the largest Province of Malaysia. On the basis of the findings of the study, some recommendations are made, which are as follows:

1) Both libraries ought to give special consideration to the user's needs and demands in reference desk service.

2) Electronic or virtual reference services ought to be acquainted by the libraries with expansion the ease of use.

3) The reference staff ought to be prepared for future service improvement in keeping up a high level of user satisfaction especially face to face services.

4) Both university libraries ought to consider the features of "Ease of use and supportiveness" while giving online or electronic services for their clients.

5) University's library programs, for example, Information Skill Class ought to target undergraduate and postgraduate who are most in need of support in the utilization of distinctive library resources and services.

6) User satisfaction study/report ought to be led at the macro and micro levels on distinctive parts of reference desk services.

7) Both universities ought to give full consideration in online or virtual training with the goal that they (librarian) getting to be more knowledgeable.

\section{Conclusion}

As a conclusion, this study suggests that both university libraries should emphasize on developing an assessment technique, measures, standards and IFLA/ALA guidelines so that librarians could provide better digital reference service to their users. It is hoped that this study can be used to assess the relevance of a physical reference desk or as a springboard for considering other multi-tasking options when experiencing declining reference desk questions. Hence, this study opens for discussions among librarians around the world to improve their research to discover the relevancy, reliability and sustainability of reference desk service in the digital world. Contributions found in this study will be useful for the improvement of library facilities and the betterment of the library profession to serve as a contribution to the body of knowledge in the relevancy of reference desk service offered in the library facilities.

\section{Acknowledgements}

The authors are indebted to the prior literature research that has been made in any anonymous journal/conference references related to Library and Information Studies (LIS) environment. The author also wishes to thank the editor for extensive assistance in the final revision of the paper to be published.

\section{References}

Brewerton, A. (2003). Inspired! Award-winning library marketing. New library world, 104(7/8), 267-277. http://dx.doi.org/10.1108/03074800310488040

Callinan, J. E. (2005). Information-seeking behaviour of undergraduate biology students: A comparative analysis of first year and final year students in University College Dublin. Library Review, 54(2), 86-99. http://dx.doi.org/10.1108/00242530510583039

Curry, A., \& Copeman, D. (2005). Reference service to international students: A field stimulation research study. The Journal of Academic Librarianship, 31(5), 409-420. http://dx.doi.org/10.1016/j.acalib.2005.05.011

Elmborg, J. (2013). Literacies, narratives and adult learning in libraries. In Learning with Adults. Sense Publishers, 185-194. http://dx.doi.org/10.1007/978-94-6209-335-5_14

Garrison, J. A. (2011). What Do We Do Now? A Case for Abandoning Yesterday and Making the Future. Reference \& User Services Quarterly, 51(1), 12-14. http://dx.doi.org/10.5860/rusq.51n1.12

Iberahim, Z., \& Mohd Nadzar, F. (2011). Service quality and user satisfaction of the reader's advisory desk service: A case study of University Putra Malaysia Library. Journal Information and Knowledge Management, 1(1), 37-54.

Light, J. C., Stokes, A., \& Haines, L. L. (2014). Library Support Of Mobile Resources During Clinical Clerkships. Library Philosophy and Practice, 33(2), 179-194.

Maharana, B., \& Panda, K. C. (2005). Virtual Reference Service in Academic Libraries: A Case Study of the Libraries of IIMs and IITs in India (pp. 1-14). 
Malik, A., \& Mahmood, K. (2014). Readiness for digital reference service (DRS) in university libraries a survey in the Punjab, Pakistan. Information Development, 30(2), 181-188. http://dx.doi.org/10.1177/02666669 13489700

Nolen, D. S. (2010). Reforming or Rejecting the Reference Desk: Conflict and Continuity in the Concept of Reference. Library Philosophy and Practice, 1-10.

Nordin, S. K., Kassim, N. A., \& Baharuddin, K. (2012). Evaluating digital reference service in university libraries (pp. 23-26). Paper presented at the Symposium on Business, Engineering and Industrial Applications (ISBEIA), 2012 IEEE. http://dx.doi.org/10.1109/ISBEIA.2012.6422870

Polger, M. A., \& Okamoto, K. (2010). "Can't Anyone Be a Teacher Anyway?": Student Perceptions of Academic Librarians as Teachers. Library Philosophy and Practice, 1-17.

Pomerantz, J., \& Luo, L. (2006). Motivations and uses: Evaluating virtual reference service from the users' perspective. Library \& information science research, 28(3), 350-373. http://dx.doi.org/10.1016/j.lisr.2006. 06.001

Rieh, S. Y. (1999). Changing reference service environment: A review of perspectives from managers, librarians, and users. The Journal of Academic Librarianship, 25(3), 178-186. http://dx.doi.org/10.1016/S0099-1333(99) $80197-9$

Schulte, S. J. (2011). Eliminating traditional reference services in an academic health sciences library: A case study. Journal of the Medical Library Association: JMLA, 99(4), 273. http://dx.doi.org/10.3163/1536-5050. 99.4.004

Sobel, K. (2009). Promoting Library Reference Services to First-Year Undergraduate Students. Reference \& User Services Quarterly, 48(4), 362-371. http://dx.doi.org/10.5860/rusq.48n4.362

Tripathi, S. (2014). Exploring the shifting paradigms of librarian-client relationship. Annals of Library and Information Studies (ALIS), 61(1), 49-55.

Vondracek, R. (2007). Comfort and convenience? Why students choose alternatives to the library portal. Libraries and the Academy, 7(3), 277-293. http://dx.doi.org/10.1353/pla.2007.0039

\section{Copyrights}

Copyright for this article is retained by the author(s), with first publication rights granted to the journal.

This is an open-access article distributed under the terms and conditions of the Creative Commons Attribution license (http://creativecommons.org/licenses/by/3.0/). 